\title{
Internet users' attitudes towards social media advertisements: The role of advertisement design and users' motives
}

\author{
Mohammad Al Haj Eid ${ }^{a *}$, Nawras M. Nusairat ${ }^{b}$, Mahmud Alkailani ${ }^{\mathrm{c}}$ and Hamad Al-Ghadeer $^{\mathrm{d}}$
}

${ }^{a}$ Ph.D. Candidate, marketing management in University of Otago, New Zealand

${ }^{b}$ Assistant Professor of Marketing and Consumer Behavior, Applied Science Private University, Jordan

${ }^{c}$ Associate Professor of Cross-cultural and Digital Marketing, Yarmouk University, Jordan

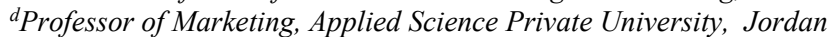

\section{H R O N I C L E}

Article history:

Received: December 28, 2019

Received in revised format:

January 302020

Accepted: February 26, 2020

Available online:

February 26, 2020

Keywords:

Advertisement attributes

Attitudes

Motives

Social media

Jordan

\section{A B S T R A C T}

This research paper aims to examine the impact of social media advertisement attributes, including informativeness, trust, and irritation, and internet users' motivational factors; namely investigation, customization, opportunity seeking, interaction, and entertainment on individuals' attitude towards advertisements over social media sites in Jordan. A conceptual research model was proposed based on the relevant literature to be empirically tested. Data was collected using an online questionnaire survey administered to 256 participants. Hypotheses were tested using single and multiple linear regression analyses. Results show that advertisement design factors along with internet users' motives were all significant factors affecting the attitude towards advertisements on social media sites with entertainment, interaction and informativeness had the highest impact. Based on the research findings, recommendations were reported for academicians and practitioners. Limitations and promising areas for further research were discussed.

\section{Introduction}

The term 'advertisement' refers to "any paid form of non-personal presentation and promotion of ideas, goods, or services by an identified sponsor" (Philip, Armstrong, \& Opresnik, 2018, p. 452). Advertisements are mainly composed of non-personal information. From different informational sources, various definitions of advertisement can be retrieved and can be defined as a propagation statement displayed in public to convey hidden messages. Advertising world has its roots in the early days of the invention of communication media. In the traditional format, advertisements are strictly known for providing factual information (Ekstrom \& Gustafsson, 2012). With time, advertisement has evolved from a mere source of cognitive information to a source of promotion, entertainment as well as social guidance (Philip et al., 2018). Literary studies define advertisements as a paid weapon used by marketers to convince customers to choose their product (Richards \& Curran, 2002). Thus, audience persuasion can be considered as the ultimate goal for advertisers. In the modern age, where the whole world has become a global village, advertisements are seen as an important element of marketing and act as a bridge between customers and companies (Chouhoud, 2013). Depending on the nature of the message conveyed, information can be divided into promotional and awareness creating. Promotional advertisements are conducted by business organizations while awareness-creating advertisements target specific groups of people, and are usually performed by non-profit organizations (Dunn, 1990). For advertisements to be effective, for both businesses and not-for-profit organizations, the advertisement should have important features such as information source, publicized information and comparative advertisements. 
Social networking sites are always an easy choice for marketing as they already have a massive user-base, which can be exploited for commercial purposes. Although the interest in internet advertising through social networking sites is increasing due to the rapid growth of internet use in Jordan, few efforts have been made to examine the perspective of customer in relation to advertisements on social networking sites. It has been cited that more than $\$ 50$ billion was generated globally using advertising over the web (Jordan Times, 2015). Investment in online advertising is increasing and therefore demands more attention in the field of business research. Jordan is a progressing environment for electronic commerce where there are more than 6 million internet users from a total population of 10 million (Alkailani, 2016). Attitudes of consumers play a major role in the effectiveness of any advertising campaign (Lou \& Yuan, 2019). Although statistics and information about internet usage and advertising expenses in Jordan are available, very little research has been made regarding peoples' attitudes and behavior towards online advertising in Jordanian spectrum. Additionally, such valuable research would help improve sales, satisfaction, feedback, and public representation for companies. This research would shed more light on the variables associated with advertising effectiveness over the web and how best utilize them.

\section{Advertisement media}

Electronic media is defined as a mode of advertisement through telecommunication tools such as televisions, radios, broadcasting, etc. Nowadays, with the development of the electronic market and information technology, electronic media is further divided into traditional and online media. Tradition media is the most common and is an old form of advertising, where radios and televisions are used for advertising a product or service. But, in online media, cybersphere is used by marketers (Lovett, 2010). The type of media is chosen by the marketer based on the type of product being advertised, price, and the audience (Gurau, 2008). These days, media fragmentation has led to the rapid absorption of internet technology (Lovett, 2010). Internet is found to be more transparent, informative, and interactive by users according to research results (Gurau, 2008). The drastic change in customer behavior and increasing web inclination are the basis of marketing reform in the shape of online advertising (Owen \& Humphrey, 2009). Online advertising has a history of 25 years and started in the form of banners (Zeff \& Aronson, 1999). Online advertisement varies from traditional marketing where a customer's role is passive and they are exposed to advertisements without expressing any interest, while customers exposed to online advertising are more active and advertisements can be personalized (Kaur, 2008). Customer-base formation on cybersphere is rather difficult as direct contact with customers is not possible. Therefore, competitive businesses choose social networking sites as their platform and use their registered users as targets for marketing (Chandra et al., 2012). Extant literature signifies the significance of social media in changing perceptions of customers in carrying out transactions (Benthaus, Risius, \& Beck, 2016; Hudson, Roth, Madden, \& Hudson, 2015; Morris and Ogan, 1996). Thus, the importance of customer-behavior on social networking sites cannot be ignored by business players.

\section{Social network-based advertising}

Social networking is a communication process where information sharing can be carried out between online members (McKenzie, 2009). Social networking site-based advertisement is a mixed communication technology allowing increased communication along with providing multiple business platforms (Mangold \& Faulds, 2009). Since the development of advertising banners on websites, companies have chosen the internet as a means of communication with clients (Adams, 1995). Thus, the internet advertising world has drastically evolved. Internet advertising can be defined as a banner or button delivering useful information about the company or the product (Schlosser et al.,1999). Internet advertisement is more customer favorable than the traditional method according to Schlosser et al. (1999). Online advertisement is rich in information source, low cost and an easy communication method that can collect an abundance of information about potential customers. It can reach a wide audience and can be customized according to customers' needs and interests (McKenzie, 2009). As online marketing is becoming more important by the day, sites where people spend most of their time, are targeted by marketers. Social networking sites are increasingly drawing users who find it good platforms to socialize with friends and colleagues. As a result, marketing companies have focused on social networking sites as their business platform. Social networking advertisement can be defined as an online advertisement circulated by the marketer (Lavidge \& Stainer, 2008). This type of advertisement can take different forms such as gaming advertisements and display advertisements. Advertising a business depends on many different factors such as information, reliability and customer motivation (Lee \& Johnson, 2005). Promotional events through advertisements either persuade customers to take action or prepare a future customer-base depending on the informative content (Richards and Curran, 2002). Furthermore, many researchers asserted that advertisement design should be mainly focused on developing positive thoughts in the customers' minds about the offered product (Philip et al., 2018). Advertisement creation and promotion require a huge financial investment. It involves a complex process based on the perception of customers towards the product and how that will affect their final decision (Kaur, 2008). Therefore, advertising research hinges on the need for developing a prior understanding of the factors related to customer perception of advertisements in order to ensure advertisement success (Ekstrom \& Gustafsson, 2012).

\section{Advertising models}

Advertising design model was initiated by Moriarty (2009) through AIDA modal development, which combines the effect of attention and interest with desire and action. Since then, many different models have been developed (Philip et al., 2018) to ensure advertising motive accomplishment (Lou \& Yuan, 2019). In order to design a perfect model for advertisement, there is a need to change design patterns along with changing customers' behavior (Philip et al., 2018). Previously, the majority of customers were approached through various communication channels including electronic and print media (Philip et al., 
2018). With the rising popularity of social networking sites, especially Facebook, they have become the most common communication tool for marketers (Champoux et al., 2012). Active users on social networking sites can easily participate in buying advertised products (Shih, 2009), thus decreasing the advertisement cost and increasing market reach. Social networking sitebased advertisements enable the promotion of new company products and help in boosting web traffic to marketers' sites (Ghazal, 2011; Tetteh, 2015). Furthermore, as online advertising is less expensive in comparison to other means of promotion, emerging entrepreneurs can also target a large population (Murray \& Waller, 2007).

\section{Attitudes defined}

Social networking sites are disadvantaged due to the failure of advertising models caused by lack of information regarding customer attitude towards advertisement, which is as crucial factor (Yuanxin \& Pittana, 2011). Good marketing strategies cannot be designed in the absence of knowledge about customers' attitudes (Kornias \& Halalau, 2012). Attitude could be positive and negative (Philip et al., 2018) according to the extent of favorability attached to feelings. Attitude has three components named as affect, cognition and behavior, which means to feel, believe or behave about/to the object (Yavuz Mumcu \& Cansız Aktaş, 2019). Customer attitude towards networking site-based advertisement is cognitive and can be positive or negative (Kornias \& Halalalu, 2012). Moreover, they are deemed to be a vital indicator of advertisement success (Mehta, 2000). Therefore, studying the factors affecting the behavior of customers is very important in designing advertisements (Mehta and Purvis, 1995) and especially for social media. Reports regarding the attitude of customers towards generalized online advertisements state the development of positive attitude in customers is linked to interactivity (Hadija et al., 2012) and personalization (Logan et al., 2012). Huge numbers of advertising models have been developed to explain attitude dependency on various factors (Kornias \& Halalau, 2012). An example of traditional advertising models includes a Pollay and Mittal model developed in 1993, which consisted of seven factors (Kornias \& Halalau, 2012) The model displayed product information, entertainment and social information as utility factors. In addition to these factors, four socio-economic factors are also included. This model is limited by factors such as the difficulty in articulating the economic factors, and considering only traditional advertisement systems, which makes this system unusable in the study of the analysis of customer attitude towards social networking site-based advertisements (Kornias \& Halalau, 2012). Another model was developed by Ducoffe in 1996. It includes information, entertainment and irritation as its three factors. Unlike Pollay and Mittal, 1993 model, socio-economic factors are not considered. These factors have been also analysed by various researchers for determining customer attitude towards the online advertisement. The model is found to be simple and effective (Kornias \& Halalau, 2012). In 2001, one additional factor, credibility, was integrated by Bracket and Carr to Ducoffe's (1996) model as a component, as it offered further explanation of the attitude toward advertising construct. Further in 2012, interactivity was added to the above-combined model by Logan et al (2012). This study has two dimensions: the first dimension focuses on the use of all the four factors described by Ducoffe (1996) and Bracket and Carr (2001), including entertainment as a factor. The second dimension of research user-related variables is analyzed. Attitude is a derived composite outcome of the interaction between a person's beliefs (cognitive thoughts) and expressed emotions (affective feelings) with respect to those beliefs. Knowledge of these interactions can help to predict a consumer's behavior (conative action) (Asiegbu et al., 2012). Review of all the attitude associated factors has been carried out by many researchers and was found to be useful (Ducoffe, 1996; Brackett \& Carr, 2001; Kornias \& Halalau, 2012; Logan et al., 2012; Lou \& Yuan, 2019).

\subsection{Attitude and information}

The first important factor of attitude is informativeness. Information is an important tool which has a huge effect on the perception developed (Akhtar et al., 2019). Thus, information availability in the advertisement should be considered a priority. The last and most important aim of any advertisement is creating awareness among customers about the product. Furthermore, based on information, it has to convince users of social networks to purchase the offered product (Bendixen, 1993). According to the study conducted by Ducoffe (1996), a direct relationship is established between information availability in advertisement and the positive attitude of the customer. It is found that there is a positive and strong relationship between the informativeness level of an advertisement and the attitude of consumers towards it. (Taylor et al., 2011). Transparency and reliability of the information provided on social networking-based advertisements have also been found to contribute to positive or negative attitudes of customers towards products or brands offered (Bauer et al., 2005). From the results of studies conducted in Jordan regarding the attitude of customers towards information provided with an advertisement, it can be concluded that information is a critical determinant of a customer's decision to buy a product. A different piece of research is carried out in Sweden by Kornias and Halalau (2012) with the purpose of assessing the factors responsible for the development of positive or negative attitudes about products based on information available on social networking advertisements. The findings indicated that information is mandatory to develop an understanding of the product. According to Luo (2002), product information promoted in advertisements on social networks should be able to convince users by providing valid reasons for product acceptance. Therefore, based on the above-cited literature, information can be taken as an important measure of attitude, thus our first hypothesis states that:

$\mathrm{H}_{1}$ : There is a significant positive impact of advertisement informativeness and the internet users' attitudes towards advertisements on social media sites.

\subsection{Attitudes and trust}

Trust is defined as the extent of reliability a customer has on the provided information about products in an advertisement 
(Lutz \& Mackenzie, 1983; Ohanian, 1990). The significance of credibility in advertisement designing is explained by Lou and Yuan (2019) as one of the important links between customers and marketers creating trust. Several experts find that distrust in the advertising medium emerges from fake product information (Percy \& Elliot, 2008). Research shows a direct positive relationship between attitude development and trust (Algharabat \& Zamil, 2013). Distrust is found to affect customer attitude negatively towards advertisements on social networks (Percy \& Elliot, 2008). Thus, the second hypothesis states that:

$\mathrm{H}_{2}$ : There is a significant positive impact of internet users to trust in social media sites and their attitudes towards social media advertisements.

\subsection{Attitudes and irritation}

The third factor of Ducoffe (1996) model is irritation. In contrast to the above-mentioned variables, irritation is a negative indicator. Tactics used by marketers can sometimes leave customers annoyed (Rettie et al., 2001). It has also been indicated that the interference of advertisements while users try to concentrate on social networking site, leads to a feeling of customer irritation, resulting in a negative attitude towards the product (Kornias and Halalau, 2012). Irritation is one of the major reasons behind customer criticism of an advertisement and can lead to sales reduction (Ducoffe, 1996). It is likely, that based on irritation, customers perceive advertisements as irritating and unwanted and can further give rise to customer dissatisfaction (Ogba et al., 2012). Luo (2002) has asserted that the negative perception of a product has arisen in relation to irritation aroused by the intrusiveness of social networking-based advertisement. In addition, Li et al. (2002) found that intrusiveness can affect the perception of customers towards marketing strategies. The degree of irritation can be measured by the extent of disturbance, distraction and intrusiveness (Ducoffe, 1996). Therefore, according to presumptions cited in the literature, irritation as a factor of advertisement should be kept in mind before designing (Gaber, 2012), therefore the third hypothesis states:

$\mathrm{H}_{3}$ : There is a significant positive impact of advertisement irritation and the internet users' attitudes towards advertisements on social media sites.

\subsection{Attitude and customization}

Customization is an important element of social networking sites (Tapia, 2010). It has been described as a contributory variable by Doucoffe (1996). Customization is defined as the ability of an organization to target their customers according to their individual personalities, needs, and way of thinking (Imhoff et al., 2001). Customizations are a unique feature of social networks-based advertisements making it an attractive source (Yuanxin \& Pittana, 2011). Without customization, it is very difficult for internet-based advertisements to survive (Gorden et al., 1997). Advertisement customization has been found to be one of the most influential factors, affecting customers' attitudes when deciding to buy (Kumar \& Benbasat, 2006; Tam \& Ho 2006). Customization as a feature, in social networking site-based advertisement refers to personalized advertisements offered to each and every customer based on demographic profile. In the modern world, there are many companies achieving sustainable growth through the techniques of customization (Tam \& Ho, 2006). Among the advantages of customization is the personalized contact between the customer and the company. It creates a strong bonding between the customer and the company and contributes to initiating a feeling of reliability. In this respect, Kornias and Halalau (2012) found that social network advertisements were more appealing to customers when being linked to their interest, which suggest that customers are more likely to form a positive attitude towards customized advertisements. Accordingly, it is hypothesized that:

$\mathrm{H}_{4}$ : There is a significant positive impact of internet users to seek for customization and their attitudes towards advertisements on social media sites.

\subsection{Attitudes and investigation}

Findings of exploratory and confirmatory analyses revealed five distinct motivation factors; "brand affiliation", "investigation", "opportunity seeking", "conversation", and "entertainment" have a significant impact for interaction with brands on social media sites (Enginkaya, 2014). Investigation or information-seeking motivation consists of the usage of social media by consumers to search for information about a product or brand (Mangold \& Faulds, 2009). According to past literature, consumers seek information through Facebook (Kneidinger, 2014). Therefore, the following hypothesis is formulated:

$\mathrm{H}_{5}$ : There is a significant positive impact of internet users seek for investigation and the internet users' attitude towards advertisements on social media sites.

\subsection{Attitudes and opportunity seeking}

Opportunity seeking motivation is a utilitarian driver representing the benefits consumers might obtain by following a brand (for instance, discounts, promotions, coupons) (Enginkaya \& Y1lmaz, 2014). Moreover, some consumers are suggested to be more cost-conscious than others, looking for promotions and better deals (Kanter \& Källström, 2019). Therefore, we hypothesize that:

$\mathrm{H}_{6}$ : There is a significant positive impact of internet users for opportunity seeking and their attitudes towards advertisements on social media sites.

\subsection{Attitudes and interaction}

Based on the literature provided, advertising through social networks has a unique feature of interaction (Yuanxin \& Pittana, 2011). The term interaction has been defined by many researchers and is identified as the major differentiating feature between 
traditional and online advertising methods (Morris \& Ogan, 1996; Rafaeli \& Sudweeks, 1997). Interaction can be defined as communication or a short intermediate action before making a purchase. Social networking sites have facilitated the process of interaction to an unimaginative extent (Winer, 2008). It allows the flow of information. Yuanxin and Pittana (2011), found that interaction is a major component affecting customer attitudes on Facebook. As compared to traditional advertising methods, social networking-based advertisements offer a platform for interaction between the customer and the company on a larger scale (Wang et al., 2007). Further, interaction has been stressed as an important strength of advertising on social networking sites (Strauss and Frost, 1999). With changing times, customers have become proactive and have shown an interest in indirectly participating in product markets. Interaction allows the customer to feel that they are a participant in the process of advertising and thus they develop a positive attitude. In order to increase their sales and promote their products, companies are including interaction as an important component in their marketing design (Kapferer, 2008), therefore it is hypothesized that:

$\mathrm{H}_{7}$ : There is a significant positive impact of internet users to seek for interaction and their attitudes towards advertisements on social media sites.

\subsection{Attitudes and entertainment}

In 1996, Ducoffe highlighted the importance of entertainment in advertising for social media. Also, as described by Ekstrom and Gustafsson (2012), entertainment is a feeling of pleasure or satisfaction. It should also be able to provide an emotional release. To develop a positive attitude in customers regarding advertisement, positive feelings should be an important part of advertisement design. According to Eighmey and McCord 1998, the extent of enjoyment felt by customers is defined as the factor of entertainment. In order to attract maximum customers, the message drawn from the advertisement should be humorous (Yuanxin \& Pittana, 2011). Social networking-based advertisements that rely on entertainment develop a more positive attitude in customers about the product than any other factor (Yuanxin \& Pittana, 2011; Alwitt \& Prabhaker, 1992). It is found that advertisers share an experience similar to that of researchers and believe that if their message is conveyed in an entertaining way, this will lead to customer attraction and hence advertisement success (Shavitt et al., 1998). Similar views of social networking site users were recorded by Hadija et al. (2012), where the majority of customers find entertaining advertisements more useful. Usually, users on social networks seek relaxation and enjoyment (Muntinga et al., 2011). Taylor et al. (2011) found that entertainment-based advertisements on social networks attract consumers and affect their attitude positively. Thus, our hypothesis states:

$\mathrm{H}_{8}$ : There is a significant positive impact of internet users to seek for entertainment and their attitudes towards advertisements on social media sites.

Based on the above discussion and inspired by the extant literature, a research model (Fig. 1), depicting the eight paths linking customer attitudes to three advertisement design-related factors and four other customer motivation-related factors was developed to be empirically tested.

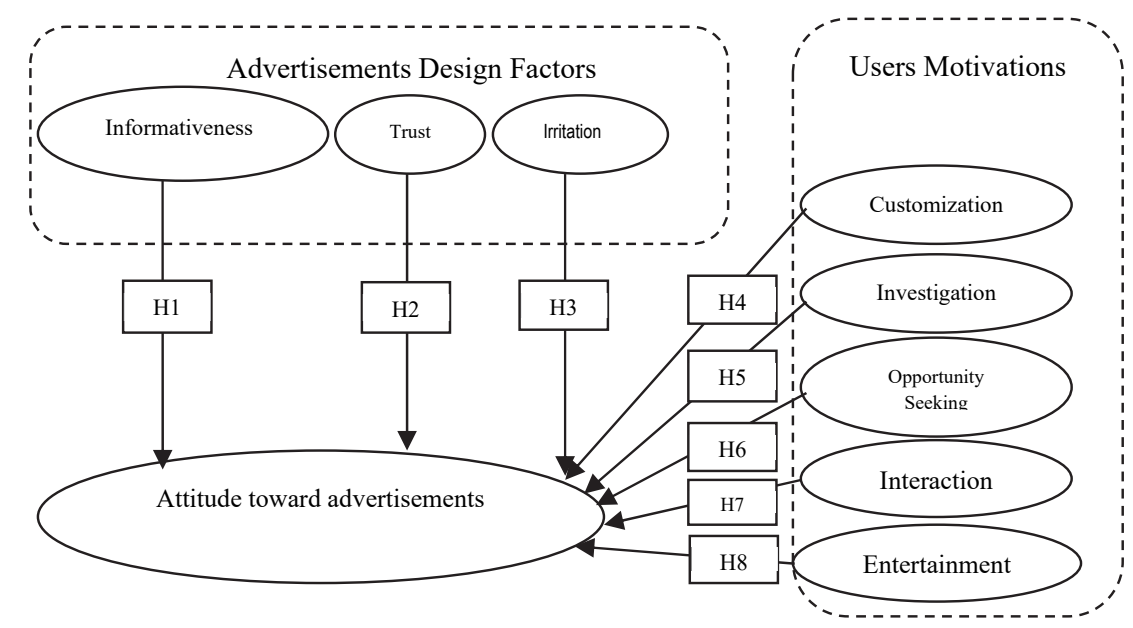

Fig. 1. Diagrammatic Model of Dependent and Independent variables

\section{Research methodology}

In order to analyze the attitude of internet users towards advertisements on social networking sites, a survey was designed and validated. The survey consisted of 2 parts, the first part of the questionnaire identifies the personal information of the respondents while the second part elaborates on independent and dependent variables that would be tested in the survey. Data was collected online using kwiksurveys.com. Questions were adapted from different validated scales (Algharabat \& Abu-Elsamen, 
2013; Ducoffe, 1996; Greyser, 1973; Campbell \& Wright 2008; Enginkaya \& Y1lmaz, 2014; Enginkaya \& Y1lmaz, 2014; Morris \& Ogan, 1996) previously used in research and then adapted to fit this study about the Jordanian culture. The questionnaire consists of two parts. The first part checked for respondents' demographics while the second part consists of 30 questions that are designed to test the relationships among variables. a 5-degree Likert scale was used to check for respondents' attitudes towards statements, where 5 indicates a strongly agree answer and 1 indicates a strongly disagree answer. A sample of 321 respondents residing in Jordan were targeted and data was collected from 256 respondents with an $80 \%$ response rate. Data collected was checked for reliability first to ensure suitability for analysis, Cronbach's alpha technique was utilized and results showed that all constructs' scores were above the acceptable .60 score (See Table1).

\section{Table 1}

Reliability Test Using Cronbach's Alpha

\begin{tabular}{lccc}
\hline Construct & Cronbach Alpha score & Construct & Cronbach Alpha score \\
\hline Attitude & .89 & Relevancy & .66 \\
Attitude & .78 & Investigation & .7 \\
Informative & .71 & Opportunity Seeking & .67 \\
Trust & .76 & Interaction & .75 \\
Irritating & .75 & Entertainment & .83 \\
\hline
\end{tabular}

The sample of this study consisted of 124 (48\%) males and 132 (52\%) female. Their ages range from 18 to above 46 with the largest group (119) (86\%) aged between 18 and 30. Most of the participants hold undergraduate (115) (45\%) and graduate (54) $(21 \%)$ degrees. The average income of participants was around 600 JDs and most of the sample (195) (76\%) use their cell phones to access the internet.

\subsection{Testing hypotheses}

To test research hypotheses, single regression, as well as multiple regressions, was conducted. Table 2 shows results for testing the first hypothesis which indicated that "There is a significant positive impact of advertisement informativeness and the internet users' attitudes towards advertisements on social media sites". The table shows that $t$-statistic was significant $(t=5.645$, Standardized Coefficients Beta $(\beta=.34, \mathrm{P}<=0)$ which indicates a positive relationship existing between the proposed variables and shows that $\mathrm{R}$ square $=.16$ which means that informativeness explained an important portion of variance in users' intention towards accepting internet advertisements $\left(\mathrm{R}^{2}=15.0, \mathrm{P}<=0\right)$ Thus, the proposed hypothesis is accepted.

Table 2

Simple Linear Regression for the impact of Informativeness on users' attitudes towards accepting advertisements on social media sites.

\begin{tabular}{cccc}
\hline R Square & Adjusted R Square & Standardized Coefficients Beta & $\mathrm{t}$ \\
\hline .16 & .16 & .34 & Sig. \\
\hline
\end{tabular}

Table 3 shows a summary of simple linear regression for testing the second hypothesis which states "There is a significant positive impact of internet users' trust in social media sites and their attitudes towards social media advertisements". Table 3 shows that trust is positively associated with users' attitudes towards online advertisements $(\beta=.32, \mathrm{t}=5.34, \mathrm{p}<=0)$, and that trust explained a significant change in users' attitudes $\left(\mathrm{R}^{2}=.20, \mathrm{p}<=0\right)$. Accordingly, the hypothesis will be accepted.

Table 3

Simple Linear Regression for the impact of Trust on users' attitudes towards accepting advertisements on social media sites.

\begin{tabular}{cccc}
\hline R Square & Adjusted R Square & Standardized Coefficients Beta & t \\
\hline 20 & .193 & .32 & 5.34 \\
\hline
\end{tabular}

Table 4 reports the result of hypothesis three, which states that "There is a significant positive impact of advertisement irritation and the internet users' attitudes towards advertisements on social media sites". Table 4 summarizes the findings where a positive relationship is shown between variables with a significant impact $(\beta=.11, \mathrm{t}=11.6, \mathrm{p}<=.0)$. the table also shows that irritation explained a little portion of the change in users' attitudes $\left(\mathrm{R}^{2}=.02, \mathrm{p}<=0\right)$. Therefore, although irritation has a statistically significant effect on users' attitudes it is of little practical significance.

\section{Table 4}

Simple Linear Regression for the impact of Irritation on users' attitudes towards accepting advertisements on social media $\underline{\text { sites }}$

\begin{tabular}{cccc} 
R Square & Adjusted R Square & Standardized Coefficients Beta & $\mathrm{t}$ \\
.02 & .011 & -0.112 & Sig. \\
\hline
\end{tabular}

Table 5 shows a summary of a simple regression to test the hypothesis four, which states "There is a significant positive impact of internet users to seek for customization and their attitudes towards advertisements on social media sites". The table shows that customization is positively associated with users' attitudes $(\beta=.07, \mathrm{t}=5.31, \mathrm{p}<=.0)$, and that customization explained $13 \%$ of the variance in users' attitudes $\left(\mathrm{R}^{2}=.13, \mathrm{p}<=0\right)$. Thus, the researchers accept the hypothesis and conclude that there is a 
positive significant relationship between customization and users' attitude.

Table 5

Simple Linear Regression for the impact of Customization on users' attitudes towards accepting advertisements on social media sites

\begin{tabular}{cccc}
\hline R Square & Adjusted R Square & Standardized Coefficients Beta & t \\
\hline .143 & .13 & 0.07 & 5.31 \\
\hline
\end{tabular}

Table 6 reports the result of hypothesis five, which states that "There is a significant positive impact of internet users to seek for investigation and the internet users' attitude towards advertisements on social media sites". Results show that investigation has a significant statistical effect on users' attitudes towards advertisements $(\beta=.07, \mathrm{t}=5.17, \mathrm{p}<=.0)$, and that investigation explained a significant portion of users' attitudes $\left(\mathrm{R}^{2}=.20, \mathrm{p}<=0\right)$. Thus, the researchers accept the hypothesis and conclude that there was a positive significant relationship between investigation and users' attitudes towards advertisements on social media sites.

\section{Table 6}

Simple Linear Regression for the impact of Investigation on users' attitudes towards accepting advertisements on social media sites

\begin{tabular}{cccc}
\hline R Square & Adjusted R Square & Standardized Coefficients Beta & t \\
\hline .209 & .201 & 0.073 & 5.172 \\
\hline
\end{tabular}

Table 7 summarizes the results for testing the hypothesis which six states "There is a significant positive impact of internet users' opportunity seeking and their attitudes towards advertisements on social media sites". The findings show a clear strong positive impact of opportunity seeking on users' attitudes towards advertisements on social media sites $(\beta=.20, t=4.73, \mathrm{p}<=.0)$, and opportunity seeking explained $10 \%$ of the change in variance of the dependent variable $\left(\mathrm{R}^{2}=.10, \mathrm{p}<=0\right)$. The results show that there is a positive relationship between opportunity seeking and users' attitudes towards advertisements on social media sites do exist.

\section{Table 7}

Simple Linear Regression for the impact of opportunity seeking on users' attitudes towards accepting advertisements on social media sites

\begin{tabular}{ccccc}
\hline R Square & Adjusted R Square & Standardized Coefficients Beta & $\mathrm{t}$ & Sig. \\
\hline .10 & .10 & 0.20 & 4.71 & .000 \\
\hline
\end{tabular}

A simple linear regression was conducted to test the hypothesis seven, which states "There is a significant positive impact of internet users' seek for interaction and their attitudes towards advertisements on social media sites". Table 8 shows that Interaction was positively associated with users' attitudes $(\beta=.32, \mathrm{t}=4.53, \mathrm{p}<=.0)$ and that interaction explained a significant proportion of the change in the dependent variable $\left(\mathrm{R}^{2}=.18, \mathrm{p}<=.0\right)$. These results confirm the there is a statistically significant impact of interaction on users' attitudes towards accepting advertisement on social media sites.

\section{Table 8}

Simple Linear Regression for the impact of Interaction on users' attitudes towards accepting advertisements on social media sites

\begin{tabular}{cccc}
\hline R Square & Adjusted R Square & Standardized Coefficients Beta & S \\
\hline .175 & .167 & 0.32 & 4.53 \\
\hline
\end{tabular}

Table 9 shows the results of testing the hypothesis eight, which states that "There is a significant positive impact of internet users to seek for entertainment and their attitudes towards advertisements on social media sites". Findings show that entertainment is positively associated with users' attitudes $(\beta=.30, \mathrm{t}=2.47, \mathrm{p}<=.0)$. Results also show that Entertainment explained $35 \%$ of the variance of users' attitudes. $\left(\mathrm{R}^{2}=.35, \mathrm{p}<=.01\right)$

\section{Table 9}

Simple Linear Regression for the impact of Entertainment on users' attitudes towards accepting advertisements on social media sites

\begin{tabular}{ccccc}
\hline R Square & Adjusted R Square & Standardized Coefficients Beta & t & Sig. \\
\hline .35 & .337 & 0.289 & 2.469 & .014 \\
\hline
\end{tabular}

To test the effect of the overall model encompassing all independent variables (Informativeness, Trust, Irritation, Customization, Investigation, Opportunity Seeking, Interaction, and Entertainment) on users' attitudes towards accepting advertisements on social media sites, a linear multiple regression was conducted to discover the nature and degree of the association between variables. Table 10 shows a summary of the findings. It is shown that the model was statistically significant and explained $50 \%$ of the variance in the dependent variable, indicating that the model is a good predictor for the proposed relationship. The table also shows that when all variables were tested in one model, they still show a significant relationship with the dependent variable. 
Table 10

Multiple linear regression for the impact of research Model variables on Users' attitudes towards accepting advertisements on social media sites

\begin{tabular}{lcccc}
\hline Model & Standard Coefficients Beta & $\mathrm{t}$ & Sig & R Square \\
\hline Informativeness & .17 & 2.073 & .04 & .50 \\
Trust & .07 & .675 & .05 & .61743 \\
Irritation & -.12 & -1.895 & .01 & \\
Customization & .08 & 1.024 & .05 & \\
Investigation & .16 & 1.731 & .02 & .01 \\
Opportunity seeking & .01 & .153 & .01 & \\
Interaction & .18 & 2.114 & .04 & \\
Entertainment & .38 & 4.314 & .000 & \\
\hline
\end{tabular}

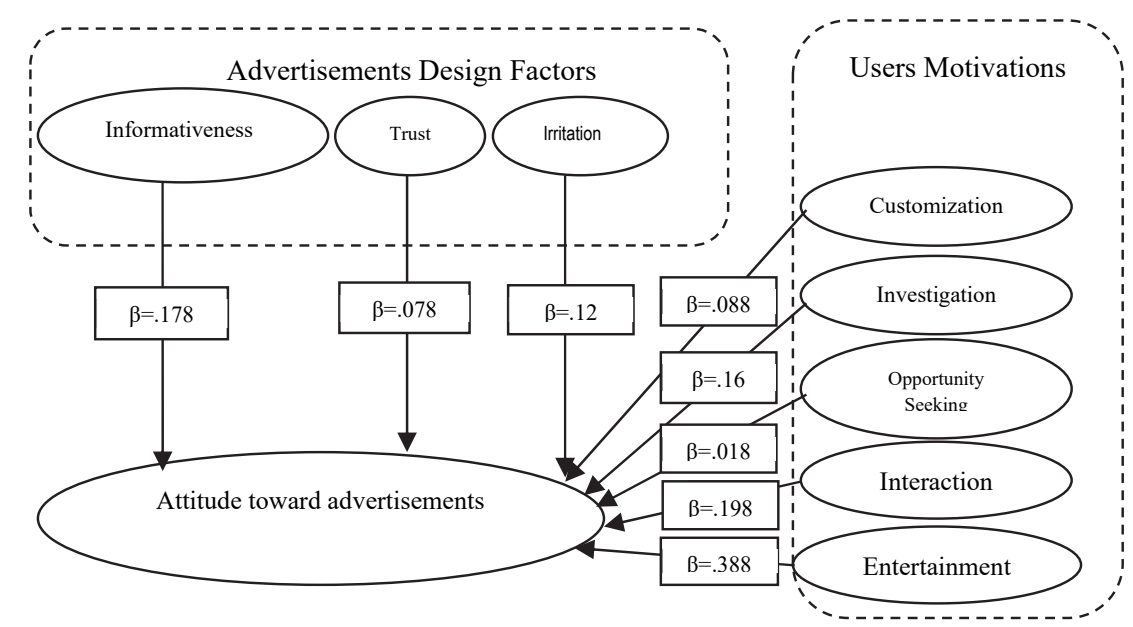

Fig. 2. Beta values for all variables included in the model

\section{Findings discussion and research recommendations}

This research was established to investigate the effect of two sets of variables on users' attitudes towards accepting advertisements on social media site; advertisements design and users' personal motivations. The model was adopted from previous research which was validated over time (Doucoffe, 1996; Bractt \& Carr, 2001; Enginkaya \& Y1lmaz, 2014). The survey distributed was initially built based on previous literature (Wolinand Korgaonker, 2003; Luo, 2010; Yuanxin \& Pittana, 2011; Kornias \& Halalau, 2012; Gaber, 2012; Ekstrom \& Gustafsson, 2012; Logan et al., 2012; Lou \& Yuan, 2019). Findings show that all variables contained in the research model have a significant positive relationship with the dependent variable (Internet users' attitudes). The findings also show that these variables contributed differently toward the explanation of proposed model relationships. Entertainment explained much of the variance in the dependent variable $(\beta=.38)$ followed by Interaction $((\beta=.19)$ as part of users' motivation factors while Informativeness showed the largest effect $(\beta=.17)$ followed by Irritation $(\beta=.12)$ among those factors related to advertisements design. These findings came in line with previous research (Kornias \& Halalau, 2012; Logan et al., 2012). Major hypotheses of this research were tested using single and multiple regression analyses, which was used to identify which of the variables contributed the most to shaping users' attitudes towards advertisements shown on social media sites. Results show a significant effect of those variables tested and that entertainment had the greatest influence on user motivation and attitudes, followed by interaction. This result is consistent with previous studies (Kornias \& Halalau, 2012; Logan et al., 2012). The results obtained from this research could be insightful to the administers of business organizations. Development of a model for advertisement strategy can lead to success if the right kind of audience is targeted by a marketer. Based on the research results, it is recommended that business organizations capitalize on the entertainment aspect of advertisements on social media sites as well as make advertisements more interactive and attractive. As the business industry and customer base continue growing and morphing, there is a need for effectively adapting advertisement models with time. Hiring professional web designers will help achieve this goal. Business organizations should also build trust with the target market by providing transparent information about products posted in the advertisements. Similarly, it would be highly beneficial to communicate any policy that would be of concern to customers before they make a purchase. Knowledge about customer attitude is a pre-requisite when it comes to creating a successful advertisement model, therefore building databases of customers and knowing which motives drive them to accept advertisements on social media will help businesses target their market more effectively.

\section{Research contribution, limitations and areas for future research}

The main contribution of this research was its attempt to fill the gap in the knowledge about users' motivational factors, advertisement design factors and their effect on users' willingness to accept advertisements on social media sites. The research 
also explored the most effective factors related to this phenomenon. Results of the present study can be implicated in the procedure of advertisement model preparation as various factors affecting attitude for social networking-based website advertisement. This research has some limitations that are common in social science research. A convenient sample was used, which limited the degree of generalization of the research results. The model has addressed two sets of variables; advertisements design factors and personal motivation factors, while other important factors (such as demographics) could be included in the model and may show a significant difference in results. It is suggested that future research take into consideration users' demographics as well as expand the sample investigated and include more variables in the model.

\section{References}

Akhtar, N., Sun, J., Chen, J., \& Akhtar, M. N. (2019). The role of attitude ambivalence in conflicting online hotel reviews. Journal of Hospitality Marketing \& Management, 1-32.

Algharabat, R. S., \& Zamil, A. M. A. A. (2013). An empirical investigation of 3D-based information systems success for online retailers. International Journal of Technology Marketing, 8(3), 316-336.

Alkailani, M., \& Kumar, R. (2016). Impacting innovativeness: The role of interpersonal influences and cultural dimensions on consumer innovativeness. Journal of Strategic Innovation and Sustainability, 11(1).

Alwitt, L. F., \& Prabhaker, P. R. (1992). Functional and belief dimensions of attitudes to television advertising: Implications for copytesting. Journal of Advertising Research, 32(5), 30-42.

Asiegbu, I. F., Powei, D. M., \& Iruka, C. H. (2012). Consumer attitude: Some reflections on its concept, trilogy, relationship with consumer behavior, and marketing implications. European Journal of Business and Management, 4(13), 38-50.

Bauer, H. H., Reichardt, T., Barnes, S. J., \& Neumann, M. M. (2005). Driving consumer acceptance of mobile marketing: A theoretical framework and empirical study. Journal of Electronic Commerce Research, 6(3), 181.

Bendixen, M. T. (1993). Advertising effects and effectiveness. European Journal of Marketing, 27(10), 19-32.

Benthaus, J., Risius, M., \& Beck, R. (2016). Social media management strategies for organizational impression management and their effect on public perception. The Journal of Strategic Information Systems, 25(2), 127-139.

Brackett, L. K., \& Carr, B. N. (2001). Cyberspace advertising vs. other media: Consumer vs. mature student attitudes. Journal of Advertising Research, 41(5), 23-32.

Champoux, V., Durgee, J., \& McGlynn, L. (2012). Corporate Facebook pages: when "fans" attack. Journal of Business Strategy, 33(2), 2230 .

Chandra, B., Goswami, S., \& Chouhan, V. (2012). Investigating attitude towards online advertising on social media - An empirical study. Management Insights, 6(1), 1-14.

Chouhoud, R. (2013). Measuring the Impact of Celebrity Endorser Attributes on Private University Students' Behavioral Intention in Egypt (master's thesis), AAST, Egypt.

Ducoffe, R. H. (1996). Advertising value and advertising on the Web. The Journal of Marketing, 53(2), 48-65.

Dunn, S. W. (1990). Advertising: its role in modern marketing (7th ed.), Chicago: DrydenPress.

Eighmey, J., \& McCord, L. (1998). Adding value in the information age: Uses and gratifications of sites on the World Wide Web. Journal of Business Research, 41(3), 187-194.

Ekström, A., \& Gustafsson, N. (2012). Consumers' Attitudes Toward Printed Green Advertising: A study of Attitudes Among Swedish Consumers.

Enginkaya, E., \& Y1lmaz, H. (2014). What drives consumers to interact with brands through social media? A motivation scale development study. Procedia-Social and Behavioral Sciences, 148, 219-226.

Gaber, H. (2012). Measuring the factors that affect young consumers' attitudes towards SMS advertisements and their purchase intentions: The case of Egypt (Master thesis), AAST, Egypt.

Ghazal, A. (2011). Motivation to Attend a Cultural Event and The Role of Social Network on Attendee's Satisfaction: The Case of Asian Film Festival (Master thesis), University of Brighton, England.

Greyser, S.A. (1973). Irritation in Advertising. Journal of Advertising Research,13(1), 3-10.

Gupta, S. (1995), HERMES: A Research Project on the Commercial Uses of the World Wide Web, http://www.umich.edu/sgupta/hermes.

Gurau, C. (2008). Integrated online marketing communication: Implementation and management. Journal of Communication Management, $12(10), 169-184$.

Hadija, Z., Barnes, S. B., \& Hair, N. (2012). Why we ignore social networking advertising. Qualitative Market Research: An International Journal, 15(1), 19-32.

Hudson, S., Roth, M. S., Madden, T. J., \& Hudson, R. (2015). The effects of social media on emotions, brand relationship quality, and word of mouth: An empirical study of music festival attendees. Tourism Management, 47(C), 68-76.

Imhoff, C., Loftis, L., \& Geiger, J. (2001). Building the Customer-Centric Enterprise: Data Warehousing Techniques for Supporting Customer Relationship Management. New York: Wiley and Sons Inc.

Kanter, D., \& Källström, O. (2019). "Wanna browse for some Black Friday deals?": An exploratory research uncovering meanings of Utilitarian and Hedonic motivation of Swedish consumers towards online shopping on consumption events with Black Friday Weekend as empirical example.

Kapferer, J.N. (2008). The New Strategic Brand Management: Creating and Sustaining Brand Equity Long Term. London: Kogan Page.

Kaur, J. (2008). Online Social Networking as an Advertising Medium, (M.Sc. thesis). Portobello College, Ireland.

Kneidinger, B. (2014). Intergenerational contacts online: An exploratory study of cross-generational Facebook (friendships). Studies in Communication Sciences, 14(1), 12-19.

Kornias, G. \& Halalau, R. (2012). Factors Influencing Users Attitude Toward Display Advertising on Facebook, (Master's thesis in Business Administration). Jonkoping, Sweden.

Kumar, A. (2012). Managing marketing mix and communications in a digital era: The role traditional and new media in a multichannel environment. Unpublished PhD Thesis, University of Buffalo, New York.

Lavidge, R. J., \& Steiner, G. A. (1961). A model for predictive measurements of advertising effectiveness. Journal of marketing, 25(6), 5962. 
Lee, M., \& Johnson, C. (2005). Principles of Advertising: A Global Perspective. United States of America: The Haworth Press Inc.

Li, H., Edwards, S. M., \& Lee, J. H. (2002). Measuring the intrusiveness of advertisements: Scale development and validation. Journal of Advertising, 31(2), 37-47.

Lou, C., \& Yuan, S. (2019). Influencer marketing: How message value and credibility affect consumer trust of branded content on social media. Journal of Interactive Advertising, 19(1), 58-73.

Lovett, K.L. (2010). Integrated Marketing Communication and the Promotion of iPhone Application. Unpublished Master Thesis, Hawaii Pacific University, Hawaii.

Luo, X. (2002). Uses and gratifications theory and e-consumer behaviors: A structural equation modeling study. Journal of Interactive Advertising, 2(2), 34-41.

Lutz, R. J., MacKenzie, S. B., \& Belch, G. E. (1983). Attitude toward the ad as a mediator of advertising effectiveness: Determinants and consequences. ACR North American Advances, 10(1), 532-539.

Mangold, W. G., \& Faulds, D. J. (2009). Social media: The new hybrid element of the promotion mix. Business horizons, 52(4), $357-365$.

McKenzie, A.B. (2009), What About Social Networking?. The Journal of Continuing Education in Nursing, 40(10), 436-437.

Mehta, A. (2000). Advertising Attitude and Advertising effectiveness. Journal of Advertising Research, 40(3), 67-72.

Mehta, A., \& Purvis, S.C. (1995). When Attitudes Towards Advertising in General Influence Advertising Success, Conference of The American Academy of Advertising, Norfolk: VA.

Moriarty, S., Mitchell, N., \& Wells, W. (2009). Advertising - Principles and Practice. Upper Saddle River, New Jersey: Pearson Education, Inc.

Morris, M., \& Ogan, C. (1996). The Internet as a mass medium. Journal of Communication, 46(1), 39-50.

Muntinga, D. G., Moorman, M., \& Smit, E. G. (2011). Introducing COBRAs: Exploring motivations for brand-related social media use. International Journal of Advertising, 30(1), 13-46.

Murray, K.E., \& Waller, R. (2007). Social Networking Goes Abroad. International Education, 16(3), 56-59.

Ogba, I. E., Saul, N., \& Coates, N. F. (2012). Predicting students' attitudes towards advertising on a university Virtual Learning Environment (VLE). Active Learning in Higher Education, 13(1), 63-75.

Ohanian, R. (1990). Construction and validation of a scale to measure celebrity endorsers' perceived expertise, trustworthiness, and attractiveness. Journal of Advertising, 19(3), 39-52.

Owen, R., \& Humphrey, P. (2009). The structure of online marketing communication channels. Journal of Management and Marketing Research, 2, 54-62.

Percy, L., \& Elliot, R. (2009). Strategic Advertising Management. Oxford University England: Press Inc.

Philip, K., Armstrong, G., \& Opresnik, M. O. (2018). Principles of marketing. Pearson Education.

Pollay, R. W., \& Mittal, B. (1993). Here's the beef: factors, determinants, and segments in consumer criticism of advertising. Journal of Marketing, 57(3), 99-114.

Rafaeli, S., \& Sudweeks, F. (1997). Networked Interactivity. Journal of Computer Mediated Communication, 2(4), 56-87.

Rettie, R., Robinson, H., \& Jenner, B. (2001). Does Internet Advertising Alienate Users? (Occasional Paper Series No 52), Kingston Business School, England.

Richards, J. I., \& Curran, C. M. (2002). Oracles on "advertising": Searching for a definition. Journal of Advertising, 31(2), 63-77.

Shavitt, S., Lowrey, P., \& Haefner, J. (1998). Public attitudes toward advertising: More favorable than you might think. Journal of Advertising Research, 38(4), 7-22.

Shih, C. (2009). Facebook Era: Tapping Online Social Networks to Build Better Products, Reach New Audiences, and Sell More Stuff, Indianapolis, USA: Pearson Education.

Strauss, J. \& Frost, R.D. (1999). Marketing on the Internet: Principles of Online Marketing. New Jersey: Upper Saddle River, PrenticeHall.

Tapia, W. (2010). An exploratory Case Study on the Effectiveness of Social Network Sites: The Case of Facebook and Twitter in an Educational Organization, (MBA thesis), Graduate Business School-Griffith College, Dublin.

Taylor, D. G., Lewin, J. E., \& Strutton, D. (2011). Friends, fans, and followers: do ads work on social networks?: how gender and age shape receptivity. Journal of Advertising Research, 51(1), 258-275.

Tetteh, V. (2015). Future of integrated marketing communications. Research Starters Business, 1, 1-77.

Wang, L. (2007). The effects of Internet advertising attitude and brand image on purchase intention: A study of online users in Taiwan, National Cheng Kung University, January 2007.

Winer, R. (2009). New communications approaches in marketing: Issues and research directions. Journal of Interactive Marketing, 23(2), $108-117$.

Wolin, L.D., \& Korgoankar, P. (2003). Web advertising: Gender differences in beliefs, attitudes and behavior. Journal of Interactive Advertising, 6(1), 125-136.

Yavuz Mumcu, H., \& Cansız Aktaș, M. (2019). Development of an attitude-towards-using-mathematics scale for high-school students and an analysis of student attitudes. International Journal of Mathematical Education in Science and Technology, 1-23.

Yuanxin, M., \& Pittana, N. (2011). A Study Investigating Attitude towards Social Media Advertising, (Master Thesis), Umea School of Business, Sweden.

Zeff, R. L., \& Aronson, B. (1999). Advertising on the Internet. London: Wiley.

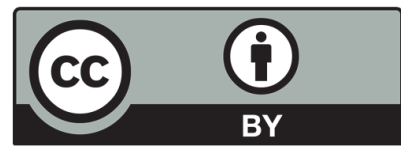

(C) 2020 by the authors; licensee Growing Science, Canada. This is an open access article distributed under the terms and conditions of the Creative Commons Attribution (CC-BY) license (http://creativecommons.org/licenses/by/4.0/). 